\title{
The role of faecal pellets in deposition of marine muddy sediments - examples from the Danish Tertiary
}

\author{
HENRIK FRIIS
}

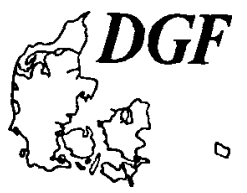

\begin{abstract}
Friis, H.: The role of faecal pellets in deposition of marine muddy sediments - examples from the Danish Tertiary. Bulletin of the Geological Society of Denmark, Vol. 42 pp. 6873. Copenhagen, 1995-10-31. https://doi.org/10.37570/bgsd-1995-42-07
\end{abstract}

\begin{abstract}
The deposition of muds may take place in various types of aggregates and pellets. In some environments this form of sedimentation has been described as important in the formation of the sediment, but very often the aggregated character of the sediment is completely lost by subsequent bioturbation, compaction or diagenesis. The paper describes examples from Danish Tertiary formations, where very early cementation by calcite or pyrite stabilized the sediment and preserved the sandy character of the muddy sediments. One example is an Oligocene shallow water lagoonal heterolith, where the mud laminae are actually well sorted pellet sand. Another example is a Paleocene hemipagic shelf mud, which in early cemented parts consist of porous pellet sand. Outside the cemented area the pelleted character is seen to disappear due to compaction. The examples demonstrate, that possible deposition of mud in high energy environments as pellets and aggregates should be considered when depositional environments are inferred.
\end{abstract}

Henrik Friis, Department of Earth Sciences, Aarhus University, DK-8000 Århus C, Denmark. November 1st, 1994.

\section{Introduction}

The formation of muddy sediments may often be related to slow deposition from suspension but there are many examples of rapid sedimentation related to deposition of aggregated mud, e.g. mud laminae in bundlewise crossbedded tidal sands, where the deposition of a mmthick mud layer may be completed in the short stagnant period at full ebb or flood (van den Berg 1981). Wells (1988) described the very rapid deposition of muds in a protected bay $(10 \mathrm{~cm} / \mathrm{y}$ at near bottom currents of $25-50 \mathrm{~cm} / \mathrm{sec}$, water depth less than $2 \mathrm{~m}$ ) by settling of very large aggregates of mud. Also the deposition of shelf muds and deep sea muds may be partly controlled by the settling of large mud aggregates (Reynolds \& Gorsline 1992). Pelleted mud may also be an important source for marine muddy sediments as described by Pryor (1975), Potter, Pryor \& Meynard (1980) and Dunbar \& Berger (1981). Kuehl, Nittrouer \& DeMaster (1988) described interlamination of quartz and faecal pellets in the sediments of the Amazon subaqueous delta. Rivers may transport and deposit mud as sandsized aggregates. Rust \& Nanson (1989) described the formation of crossbedded mud, deposited as sand-sized pedogenic aggregates of mud in an Australian river. The sandy character was lost during compaction.

In all these cases, the mud was deposited as much larger particles, and had settling velocities or hydro- dynamic behavior much different from mud. Turner (1977) reported high settling velocities for pellets in a marine environment (up to $153 \mathrm{~m} /$ day).

However, the aggregated character of the deposited mud is very often lost due to later bioturbation or compaction (Wanless, Burton \& Dravis 1981), and the original character of the sediment and the depositional processes is totally obscured. The loss of original textures may lead to erroneous conclusions as to the energy level and oxygen status of the depositional environment.

Examples from Danish Tertiary sediments are demonstrated from early diagenetic syndepositional concretions, which have retained their original texture. Pellets are observed on polished slabs and in thin sections of samples from northern Jylland (Skyum Bjerge and the borehole at Harre, Fig. 1).

\section{The Vejle Fjord Formation, Late Oligocene}

Spectacular examples of mud deposition as faecal pellets are the heterolithic and muddy sediments of the Vejle Fjord Formation. The fine-grained lithologies of the Vejle Fjord Formation are rather homogeneous silty muds or interlaminated silt and mud. The homogeneous muds are generally brownish black, and they 
are rich in organic matter ( $9 \%$, Radwanski, Friis \& Larsen 1975) and pyrite (5\%, Friis 1994). They may be visibly bioturbated, but usually appear massive. Such sediments are characteristic parts of the Vejle Fjord Formation in exposures from northern to southern Jylland and have been interpreted as lagoonal and intertidal deposits by Radwanski et al. (1975), Mikkelsen (1983), Andreasen (1985), Sandersen (1985) Andreasen \& Friis (1986) and Beyer (1987). At a few locations the sediment contains carbonate concretions or cemented layers; the uncompacted fabric and the high minus cement porosity indicate that they formed soon after sediment deposition. Fig. 2 is a cemented interbedded siltstone and mudstone from Skyum Bjerge in northern Jylland. It is clear from the photo, that the muddy part of the sediment is actually also well sorted pellet sand. Due to precompactional cementation, the original texture of the pelleted mud is still preserved. Compaction would have obliterated the sandy character of the muddy material and concealed the fact that it was deposited under conditions, where currents were capable of sorting sand-sized pellets from quartzo-feldspatic silt. The cemented layer is approximately $10 \mathrm{~cm}$ thick and represent a very rapid deposition, asestimated from the lack of bioturbation, which is elsewhere a prominent feature. It may therefore be estimated, that deposition took place within a very short period, which was dominated by relatively high and slightly variable energy conditions. The mud laminae do not neccessarily represent periods of quiesence but may also represent current conditions as indicated by the slight imbrication of the pellets. Apparantly, the sorting mechanism was rather effective, but the availability of sediment may also have influenced the sorting.

Other concretions demonstrate (Fig. 3) finely interlaminated silt and mud which has been only partly homogenized through bioturbation by deposit feeders. The original interlamination of silt and mud is a reflection of very selective sorting since the mud laminae consist of pellets, which are well sorted, alternating also with extremely well sorted silt (Fig. 4). The very early cementation prevented the obliteration of the original pelleted texture by compaction. As seen from Fig. 4 the composition of the faecal pellets is very much the same as the average sediment which contain the pellets, i.e. some organic matter, clay and minor amount of silt sized quartz, feldspar and mica. These pellets presumably represent the remnants of a tasty sediment, which has been digested by a deposit feeder and delivered at the sea bottom. The pellets were then transported and sorted according to their size and probably very low density. Haven \& Morales-Alamo (1968) recorded pellet densities close to that of seawater; in the present case the pellet density was probably somewhat higher, because of intermingled silt grains. The sorting may represent a delicate change in transporting currents, not sufficient for the deposition from suspension, nor for transportation of sand size quartz grains, but enough for transportation and sorting

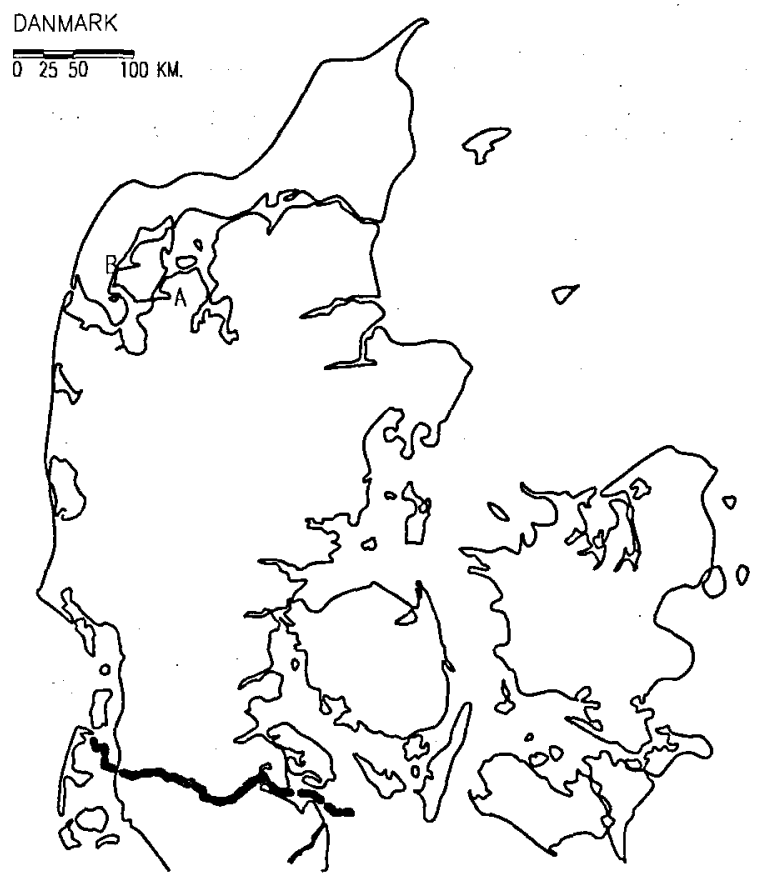

Fig. 1. Sample locations: A (Harre), B (Skyum Bjerge).

of silt and the hydrodynamically similar faecal pellets. So, disregarding the pelleted texture of the mud laminae, they appear to be poorly sorted silty mud, which might reflect deposition in quiet water. These laminae alternate with well sorted silt, which represent deposition by weak currents. The deposition might then be interpreted as deposition from alternating current/ slack water periods, e.g. in tidal systems. However, the preserved textures demonstrate that although there was variation in current strenght, there was probably only very slight changes, and slack water conditions probably were not important for deposition of the mud laminae.

It is also obvious from Fig. 3 that bioturbation is an important process for destruction of the original textural evidence for the depositional mode. The bioturbated part of Fig. 3 shows a complete homogenization of the two different lithologies, and the pelleted character of the mud laminae is gradually lost in the bioturbated part of the sediment although it may be faintly visible inside the burrow (Fig. 5).

The production of faecal pellets by deposit feeders does not explain the deposition of mud, only the redeposition and rearrangement of the mud in current bedded sediment. It may represent tranportation of pelleted mud from areas of suspension deposition into areas of more regular current deposition, and it may represent the recycling of mud which was originally deposited by suspension feeders as their faecal pellets, as described by Pryor (1975).

Also in homogeneous mud, the presence of pellets 


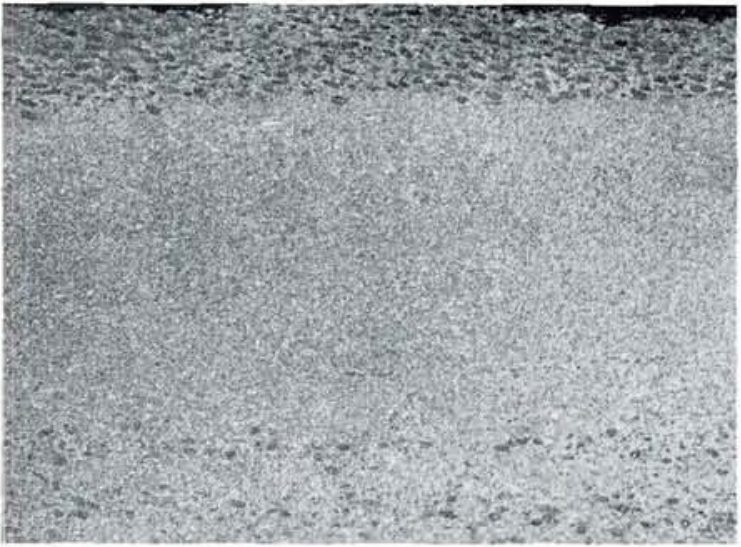

Fig. 2. Oligocene siltstone with laminae of faecal pellets, calcite cemented. Loc. Skyum Bjerge. X 1.3. (Photo by Søren Bo Andersen).

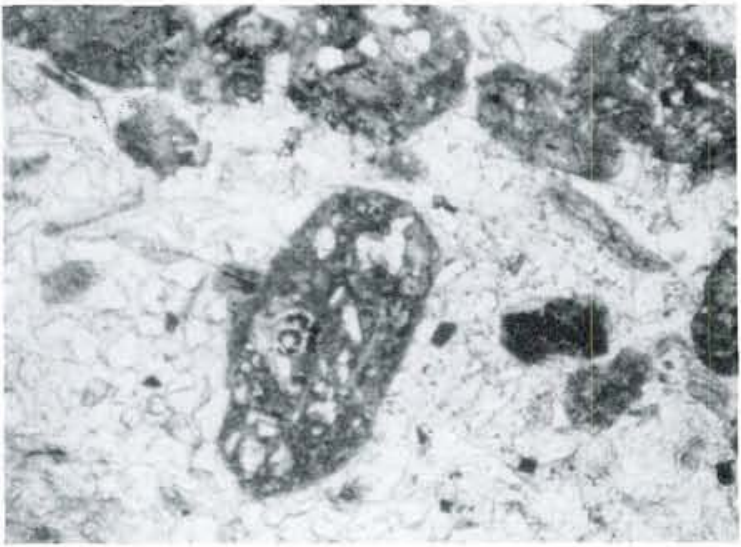

Fig. 4. Oligocene siltstone with faecal pellets, calcite cemented. Loc. Skyum Bjerge. The pellets are composed of silt-sized quartz and feldspar, mica and occationally tests of foraminifera, organic matter and clay. Thin section, width of photo: $1.1 \mathrm{~mm}$.

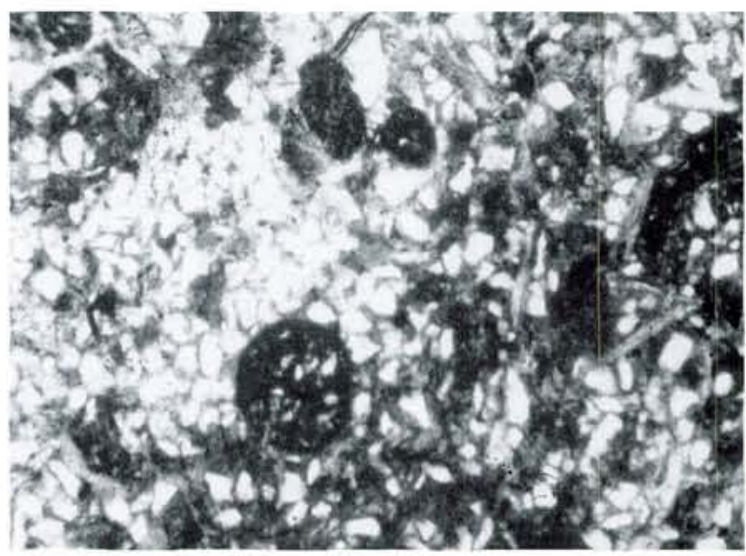

Fig. 5. Oligocene siltstone with faecal pellets, calcite cemented. Loc. Skyum Bjerge. Upper left: Inside the bioturbated part of the sediment the outline of faecal pellets is partly obliterated. Thin section, width of photo: $1.35 \mathrm{~mm}$.

\section{Grey non-calcareous Clay, Late Paleocene}

A few concretions from the informal lithostratigraphic unit "Grey slightly to non-calcareous Clay" from the Harre borehole (Nielsen 1994) were studied. The sediment is generally homogeneous silty clay, with a low content of organic matter (Nielsen 1994). In thin section the general appearance of the sediment is a light colored, homogeneous clay with minor amount of siltsized grains. The concretions are only slightly cemented, apparently mostly by cristobalite. Carbonate is not found as cementing agent. It was not possible to observe any textural inhomogeneities in the concretion except from small areas which were cemented by pyrite (Fig. 7). These areas clearly consisted of well sorted faecal pellets, which originally constituted a highly porous 


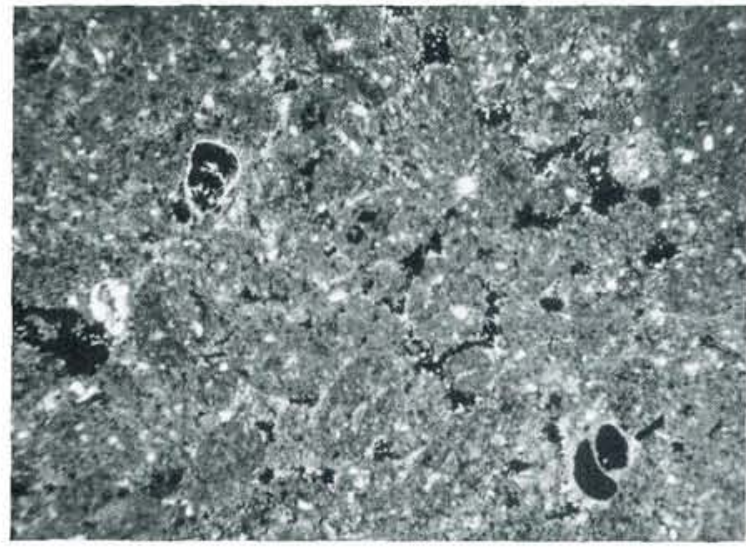

Fig. 6. Oligocene mudstone, calcite concretion. Harre borehole, $41.25 \mathrm{~m}$ below surface. Faecal pellets in pyrite cementented part. Thin section, width of photo: $2.0 \mathrm{~mm}$.

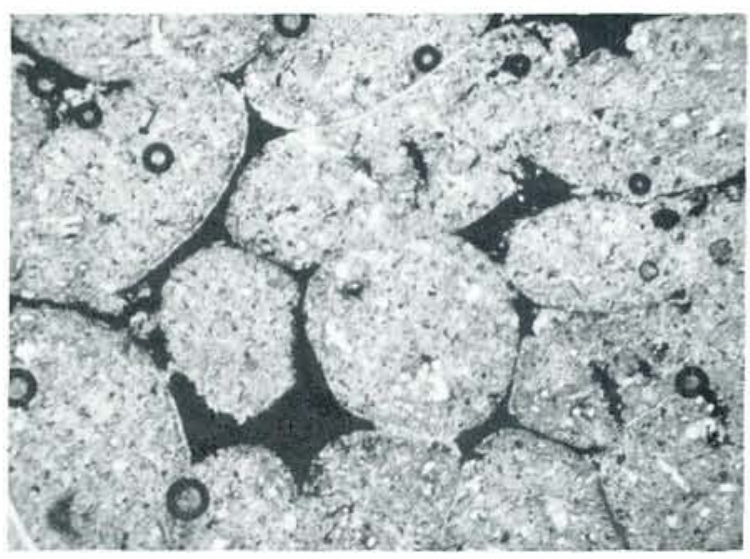

Fig. 7. Paleocene mudstone, cristobalite concretion. Harre borehole, 240,65 m below surface. Faecal pellets in pyrite cemented part. Note the sandy porous character of the sediment before cementation by pyrite. Thin section, width of photo: $3.0 \mathrm{~mm}$.

sand. The original porosity is now filled by pyrite, which predates the concretion forming cristobalite. Marginal to the pyrite cemented area, pellets are obviously present (Fig. 8) but their outlines fade away into the homogeneous sediment. The internal texture of the pellets is identical to the surrounding sediment. In a few places within the concretion, a pelleted texture is faintly visible, but the contrast between pellets and surrounding sediment is very low.

The occurrence of pellets is not neccessarily of importance in relation to interpreting the energy of the depositional environment. In the Paleocene example, the texture of the pellets is identical to that of the surrounding sediment. It cannot be decided whether the entire concretion consisted of porous pellet sand

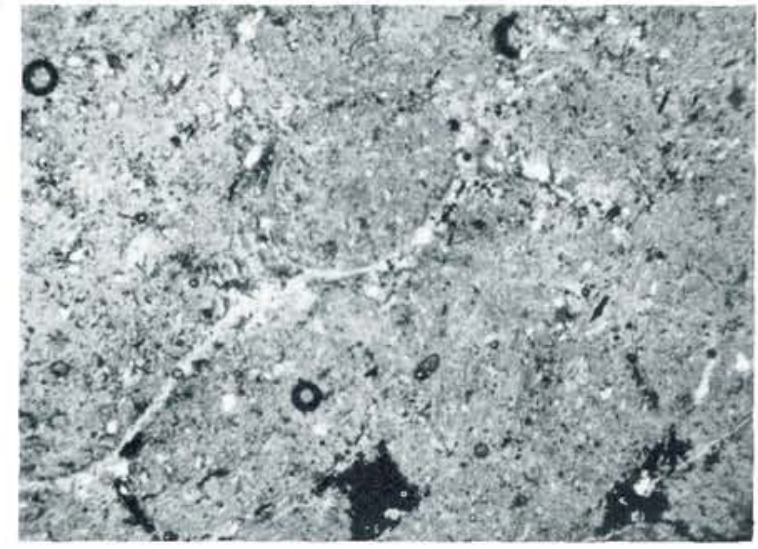

Fig. 8. Paleocene mudstone, cristobalite concretion. Harre borehole, $240,65 \mathrm{~m}$ below surface. Faecal pellets, slightly compacted. The outline of individual pellets is still visible but is partly obliterated away from the pyrite cemented part. Thin section, width of photo: $3.0 \mathrm{~mm}$.

and only minor parts were preserved due to very early pyrite cementation, which protected against compaction and perhaps also further bioturbation. The pellets appear to be sorted, but the uniform size may also be related to a single animal producer of the pellets, therefore being of equal size. The pellets could be a result of the activity of deposit feeders, which delivered the faeces in small heaps on the surface of the sediment or inside burrows, and the concentration of pellets could have controlled the diagenesis, resulting in early precipitation of pyrite. Therefore the observed pelleted mud may be the only part of the sediment which is not a hemipelagic mud, and thus the preservation of the pellets could also be a consequence of their presence.

The pellets only consist of mud, and there is no textural evidence that currents influenced the deposition. They may result from either suspension feeders or deposit feeders and their presence does not give a definite clue to the depositional environment. However, the entrapment of suspended sediment by suspension feeders enlarges the possible range of depositional environment and also makes current influenced environments possible. In spite of their very low density, the pellets will possess the potential for rapid deposition, also in a current influenced depositional environment. In most cases bioturbation and compaction will completely obliterate such an original texture (as indicated by Figs 3 and 5), but it is important to acknowledge the possibility, that muddy sediments were actually deposited as aggregated mud and not by simple drop out from suspension. Such aggregates might still deposit at relatively high energy levels. 


\section{Conclusions}

Very early cementation may preserve an original sandy texture in muddy sediments. This texture is likely to be obliterated by subsequent bioturbation, compaction or diagenesis.

The muddy facies of the Vejle Fjord Formation (Oligocene) were in some casesevidently deposited as well sorted sand-sized faecal pellets. This applies to both homogeneous silty mud and to heteroliths. Interlaminated silt of quartz and feldspar and pelleted mud indicate that deposition took place under slightly varying current condition. Also the homogeneous mud was in some cases deposited by currents. Bioturbation homogenizes the sediment and destroys the pelleted texture.

Early diagenetic cements have preserved sand-sized pellets in hemipelagic mud of the grey, non-calcareous clay (Paleocene). Where the cement is absent, the pelleted texture has been obliterated by compaction.

The muddy sediments may have been deposited under higher energy conditions than previously recognized. However, the major part of these sediments is uncemented, and the recognition of a pelleted texture is probably not possible except in a few early formed concretions.

\section{Acknowledgements}

The journal referees J. Huggett and G. K. Pedersen are thanked for their constructive comments to the manuscript.

\section{Dansk Sammendrag}

Aflejringen af finkornede sedimenter forudsættes ofte at foregå under meget rolige aflejringsforhold, hvor meget små partikler kan bundfaldes $i$ det rolige vand. Der kendes dog mange eksempler på recente aflejringsmiljøer, hvor de enkelte småpartikler er klumpet sammen i aggregater, evt. i fækalier fra organismer, der filtrerer havvand eller æder af sedimentet. Sådanne aggregater kan aflejres under mindre rolige forhold end de enkelte småpartikler, og derved mistes relationen mellem aflejringsforhold og sedimentets kornst $\varnothing \mathbf{r}-$ relse. Når aggregaterne er aflejret kan bioturbation og kompaktion meget hurtigt udviske vidnesbyrd om aggregaternes oprindelige natur.

Fra danske aflejringer beskrives eksempler på, hvorledes en meget tidlig cementering af sedimentet har fastfrosset den oprindelige aflejringstextur og afslører, at den lerede komponent i sedimentet blev aflejret som velsorterede partikler i sandfraktionen - pellets, der må antages at være ekskrementer fra marine smådyr.
Særligt iøjnefaldende er nogle silt- og glimmerlersprøver fra den $\emptyset v r e$ oligocæne Vejle Fjord Formation i Limfjordsområdet (Fig. 1, 2-6). Fig. 2-6 viser, hvorledes det, der i ukonsoliderede sedimenter er veksellejret silt og glimmerler, i virkeligheden er tynde laminæ af kvarts-feldspat silt vekslende med tynde sandlag, hvor de enkelte sandskorn er glimmerlerspellets. Sorteringen har været meget god, vekslende mellem silt og "sand". Variationerne $i$ den aflejrende strøm kan have være ganske små, og der har antagelig ikke været strømstille i forbindelse med aflejringen af glimmerleret, da der nærmest kan ses en slags imbrikation af pellets (Fig. 2). Også en tidlig cementeret prøve af rent glimmerler (fra Harre Boringen) viser sig i tyndslib at bestå af velsorteret porøst pelletsand.

Også i de meget finkornede sedimenter fra palæocæn (Grăt kalkfrit ler, Harre Boringen) forekommmer tidligt hærdede partier, der har bestået af porøst pelletsand (Fig. 7). De enkelte pellets kan erkendes en lille smule væk fra det cementerede område (Fig. 8), men deres konturer udviskes så, antagelig på grund af kompaktion. Det er derfor ikke muligt at danne sig et indtryk af det samlede omfang af denne særlige form for sedimentation, men det er vigtigt at have opmærksomheden henledt på, at sedimentation af endda meget finkornede sedimenter kan være foregået under energiforhold, der egentlig ikke tillader sedimentation fra suspension.

\section{References}

Andreasen, A. D. 1985: En sedimentologisk unders $\varnothing$ gelse af $\emptyset$.oligocæn-n.miocæn ved Bjerringbro og Ulstrup, Midtjylland. Cand. scient. thesis, Aarhus Universitet, $150 \mathrm{pp}$.

Andreasen, A. D. \& Friis, H. 1986: A tidal channel fill sequence. An example from the Upper Oligocene at Bjerringbro, Denmark. In: J.T. Møller (ed.), Twentyfive Years of Geology in Aarhus. Geoskrifter nr. 24, Aarhus Universitet, 61-68.

Berg, J. H. van den 1981: Rhytmic seasonal layering in a mesotidal channelfill sequence, Oosterschelde Mouth, the Netherlands. In: S. D. Nio, R. T. E. Schüttenhelm and T, C. E. Weering (eds.), Holocene marine sedimentation in the North Sea Basin. Special Publications of the International Association of Sedimentologists 5, 147-159.

Beyer, C. 1987: Ø. oligocæn - n. miocæn i Nordvestjylland. Faciesanalyse og magnetostratigrafi. Cand. scient. thesis, Aarhus Universitet, $164 \mathrm{pp}$.

Dunbar, R. B. \& Berger, W. H. 1981: Fecal pellet flux to modern bottom water sediment of Santa Barbara Basin (California) based on sediment trapping. Geological Society of America Bulletin Part I, 92, 212-218.

Friis, H. 1994: Lithostratigraphy and sedimentary petrography of the Oligocene sediments from the Harre borehole, Denmark, Aarhus Geoscience 1, 35-43.

Haven, D. S. \& Morales-Alamo, R. 1968: Occurrence and transport of faecal pellets in suspension in a tidal estuary. Sedimentary Geology 2, 141-151. 
Kuehl, S. A., Nittrouer, C. A. \& DeMaster, D. J. 1988: Microfabric study of fine-grained sediments: observations from the Amazon subaqueous delta. Journal of Sedimentary Petrology 58, 12-23.

Mikkelsen, J. 1983: En lithofaciesunders $\emptyset$ gelse af ungtertiaret omkring Vejle Fjord. Cand. scient. thesis, Aarhus Universitet, $100 \mathrm{pp}$.

Nielsen, O. B. 1994: Lithostratigraphy and sedimentary petrography of the Paleocene and Eocene sediments from the Harre borehole, Denmark. Aarhus Geoscience 1, 1534.

Potter, P. E., Maynard, J. B. \& Pryor, W.A. 1980: Sedimentology of Shale. Springer Verlag, New York, $310 \mathrm{pp}$.

Pryor, W.A. 1975: Biogenic sedimentation and alteration of argillaceous sediments in shallow marine environments. Geological Society America Bulletin 86, 1244-1254.

Radwanski, A., Friis, H. \& Larsen, G. 1975: The miocene Hagen $\varnothing \mathbf{r}-B \varnothing r u p$ sequence at Lillebælt (Denmark): its biogenic structures and depositional environment. Bulletin of the geological Society of Denmark 24, 229-260.

Reynolds, S. \& Gorsline, D. S. 1992: Clay microfabric of deep-sea, detrital mud(stone)s, California Continental Borderland. Journal of Sedimentary Petrology 62, 41-53.

Rust, B. R. \& Nanson, G. C. 1989: Bedload transport of mud as pedogenic aggregates in modern and ancient rivers. Sedimentology 36, 291-306.

Sandersen, P. E., 1985. En sedimentologisk undersøgelse af ungtertiæret langs den nordlige del af Lillebælt. Cand. scient. thesis, Aarhus Universitet, 244 pp.

Turner, J.T. 1977: Sinking rates of fecal pellets from the marine copepod Pontella maedii. Marine Biology 40, 249259.

Wanless, H. R., Burton, A. E. \& Dravis, J. 1981: Hydrodynamics of carbonate faecal pellets. Journal of Sedimentary Petrology 51, 27-36.

Wells, J. T. 1988: Accumulation of fine-grained sediments in a periodically energetic clastic environment, Cape Lookout Bight, North Carolina. Journal of Sedimentary Petrology 58, 596-606. 